\title{
Excimer Laser Use in Percutaneous Coronary Intervention
}

\author{
Judit Karácsonyi $i^{1,2}$, J. Roberto Martínez-Parachini', Imre Ungi², \\ András Katona ${ }^{2}$, Viktor Sasi ${ }^{2}$, Ferenc T. Nagy ${ }^{2}$, Evangelia Vemmou', \\ llias D. Nikolakopoulos', Bavana V. Rangan', Emmanouil S. Brilakis'
}

\author{
${ }^{1}$ Minneapolis Heart Institute and Minneapolis Heart Institute Foundation, Abbott Northwestern Hospital, \\ Minneapolis, MN, USA \\ ${ }^{2}$ Division of Invasive Cardiology, Second Department of Internal Medicine and Cardiology Center, University of \\ Szeged, Szeged, Hungary \\ ${ }^{3}$ Vanderbilt University Medical Center, Nashville, TN, USA
}

Corresponding Author:

Emmanouil S. Brilakis, MD, PhD, Minneapolis Heart Institute, 920 E $28^{\text {th }}$ Street \#300, Minneapolis, Minnesota 55407 E-mail: esbrilakis@gmail.com. Telephone: 612-863-3900,Fax:612-863-6441

\begin{abstract}
Excimer laser coronary atherectomy (ELCA) can be used during complex percutaneous coronary interventions (PCls) to debulk and modify the tissue with photochemical, photothermal, and photokinetic mechanisms without causing significant vessel injury. ELCA can facilitate treatment of balloon uncrossable, balloon undilatable, in-stent restenotic, saphenous vein graft and thrombotic lesions. Potential complications include perforation and dissection. Judicious use of ELCA can improve the outcomes of complex $\mathrm{PCl}$.

Keywords: laser, percutaneous coronary intervention, complex coronary lesion
\end{abstract}

\section{Az excimer lézer alkalmazása perkután koronáriaintervenció során}

Az excimer lézer koronáriaaterektómia (ELCA) komplex perkután koronáriaintervenciók $(\mathrm{PCl})$ során alkalmazható plakkok módosítására, roncsolására, fotokémiai, fototermikus és fotokinetikai mechanizmus segítségével anélkül, hogy jelentősen károsítaná a koronária ép szöveteit. A lézer aterektómia elősegíti a ballonnal áthatolhatatlan, tágíthatatlan, a korábban implantált stentben resztenotikus, a vénagraft és trombotikus léziók kezelését. Potenciális komplikációk közt a koronáriaperforáció és disszekció említendő. Az ELCA körültekintő használatával a komplex koronáriaintervenciók hatékonyságát és biztonságát fokozhatjuk.

Kulcsszavak: lézer, percutan koronariaintervenció, komplex koronárialézió

\section{Introduction}

Use of excimer laser coronary atherectomy (ELCA) has evolved over time and is currently used in complex percutaneous coronary interventions (PCls). The U.S. Food and Drug Administration (FDA) approved ELCA in 1992, and it is currently indicated for the following scenarios: occluded saphenous vein bypass grafts (SVG); long (>20 $\mathrm{mm}$ in length) lesions; ostial lesions; moderately calcified lesions; eccentric lesions; chronic total occlusions crossable with a guidewire; balloon refractory lesions; and in-stent restenosis (1). In this review we summarize the use of excimer laser in contemporary $\mathrm{PCl}$.

A kézirat 2020. 09. 30-án érkezett a szerkesztőségbe, 2020. 10. 05-én került elfogadásra. 


\section{The basics}

The term laser is derived from the acronym "Light Amplification by Stimulated Emission of Radiation", while the term excimer is derived from "excited dimer" (2). ELCA stimulates the electrons and elevates them to a higher energy level with electromagnetic energy. When the electrons return to their baseline energy level, protons are released, resulting in monochromatic light emission. ELCA applies a xenon-chloride (XeCl) excimer laser to create bursts of ultraviolet light pulses at 308 nanometers with pulse frequency of $25-80 \mathrm{~Hz}$ and fluence of $30-80 \mathrm{~mJ} / \mathrm{mm}^{2}$. Saline flush is essential during laser application to prevent a transient bubble phenomenon and to assist the laser to reach the tissue, since blood and contrast absorb $308 \mathrm{~nm}$ light avidly.(3) This was not implemented in early use of laser, which at least in part explains the high rate of complications such as dissection, abrupt vessel closure and spasm $(4,5)$.

Excimer laser ablates tissues in three ways: photochemical, photothermal and photokinetic. The photochemical mechanism means fracture of molecular bonds: the UV light pulse hits the plaque and is highly absorbed, with each photon carrying enough energy to break the bond. Second, the photothermal mechanism refers to tissue vaporization, where molecular bonds are vibrated during the absorption resulting in heat. The intracellular water is vaporized resulting in cell rupture and vapor bubble creation. The last mechanism is photokinetic, the quick expansion and collapse of the vapor bubbles helps break down the plaque, but also assists in clearing byproducts of ablation, such as gases and small particles. The majority of these particles are cleared by the reticuloendothelial system, decreasing the risk of distal embolization (2).

Currently the laser equipment used clinically is produced by Philips (formerly Spectranetics). The system includes a laser unit, which creates the laser beam and a series of catheters, which transmit the energy by fiber optics to the tip of the catheter and the target lesions. Laser catheters are available in various sizes $(0.9 \mathrm{~mm}, 1.4 \mathrm{~mm}, 1.7$ $\mathrm{mm}$ and $2.0 \mathrm{~mm}$ in diameter) with both over-the-wire and rapid-exchange/monorail versions. There are also concentric and eccentric multifiber versions (2). Laser can be used with any 0.014 " guidewire, which is a great advantage compared with other atherectomy techniques such as rotational and orbital atherectomy. For coronary catheters the device can be operated for $10 \mathrm{~s}$ (during this time 200 individual laser pulses could be delivered), followed by a 5 $s$ rest period, while peripheral ELCA catheters can operate continuously, without a resting period (3).

\section{Clinical studies and current use of ELCA}

Early studies with laser were performed before the stent era. Cook et al. showed that ELCA was an effec- tive and safe treatment option for lesions identified as not ideal for balloon angioplasty in 1991 with $84 \%$ acute laser success and $94 \%$ procedural success. ELCA was also used in chronic total occlusions with $72 \%$ success (6). The Amsterdam-Rotterdam trial (AMRO) randomized 103 patients with $>10 \mathrm{~mm}$ long functional or total coronary occlusions to laser vs. balloon angioplasty and showed angiographic success rates of $65 \%$ and $61 \%$, respectively, with similar incidence of complications (7). In the Excimer laser, Rotational atherectomy, and Balloon angioplasty Comparison (ERBAC) study, published in 1997, 685 patients were randomized to one of the three treatment modalities: balloon angioplasty, rotational atherectomy or excimer laser. Rotational atherectomy demonstrated the highest success rates, but the incidence of restenosis was equally high with all three modalities. Nevertheless, these studies applied an old laser catheter type without saline flush and stenting was only performed in the ERBAC study when occlusive dissections could not be treated with prolonged balloon inflations (5). Following the development of drug eluting stents and also due to high device cost, the use of laser decreased until recently, when ELCA re-emerged as an important treatment strategy for complex coronary lesions (8).

ELCA is often used in balloon undilatable lesions, which are lesions that do not expand despite high-pressure balloon inflations. These lesions can be treated with one or more buddy wires, cutting balloons, Angiosculpt, rotational atherectomy, orbital atherectomy, intravascular lithotripsy or laser (9). In a study by Fernandez et al, ELCA \pm rotational atherectomy was used in 58 patients with balloon failure, including 22 patients with balloon undilatable lesions, 2 of whom (9\%) had chronic total occlusions. All lesions were successfully treated; one case with rotational atherectomy and the other one with ELCA. In one CTO case a Type I (contained) perforation occurred without extravasation, related to subsequent balloon dilatation after ELCA use, and was successfully treated with drug-eluting stents (10). In the LEONARDO (early outcome of high energy Laser [Excimer] facilitated coronary angioplasty ON hARD and complex calcified and ballOon-resistant coronary lesions) registry, ELCA was used successfully in 30 of 32 (93.7\%) balIoon failure cases without any major complications (11). The LAVA study (LAser Veterans Affairs) examined laser use among veteran patients undergoing PCls and demonstrated that balloon undilatable lesions were the second most common indication with laser use $(40.8 \%$ of the cases) with high technical and procedural success rates of $94.3 \%$ and $93.8 \%$ respectively (12).

Another possible application of laser is the dilation of instent restenotic lesions. In this subgroup of lesions if the standard laser with saline flush fails, lasing during contrast injections could be applied (Figure 1). This technique should be used only with $0.9 \mathrm{~mm}$ catheters and with great caution, as it can cause perforations or vessel 

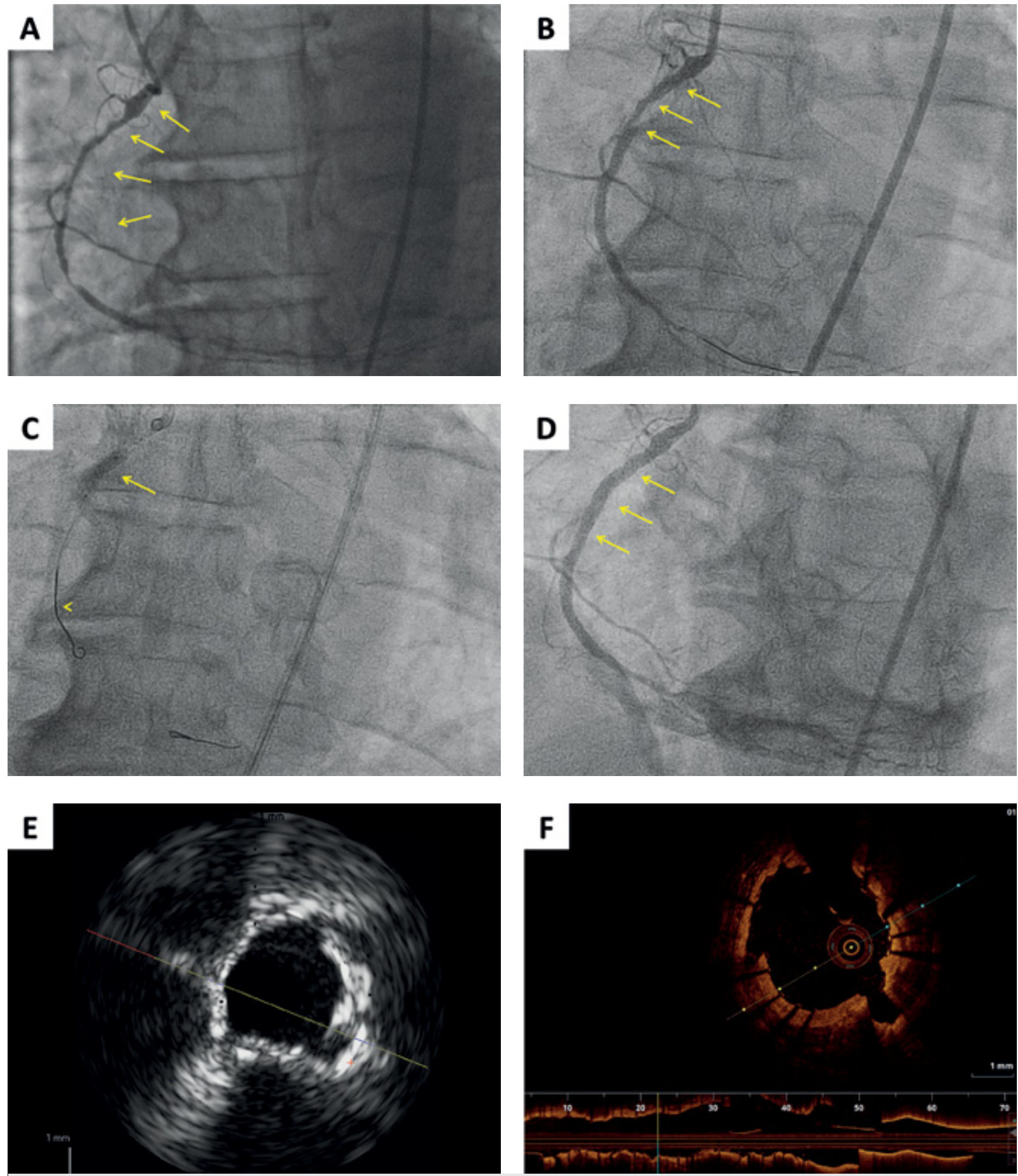

FIGURE 1. Laser coronary atherectomy during contrast injection for treating an under-expanded stent

PANEL A: Coronary angiography demonstrating a long calcified right coronary artery lesion

PANEL B: Stent underexpansion (arrows)

PANEL C: Waist in postdilation balloon (arrow) in spite of high pressure inflation and use

of a buddy guidewire (arrowhead)

PANEL D: Stent expansion after activation of laser during contrast injection

PANEL E: Intravascular ultrasonography demonstrating good stent expansion (minimal lumen area: $8.2 \mathrm{~mm}^{2}$ )

PANEL F: Optical coherence tomography demonstrating good stent expansion with extensive sub-stent dissections.

Figure reproduced from "JACC Cardiovascular Interventions" with permission. 


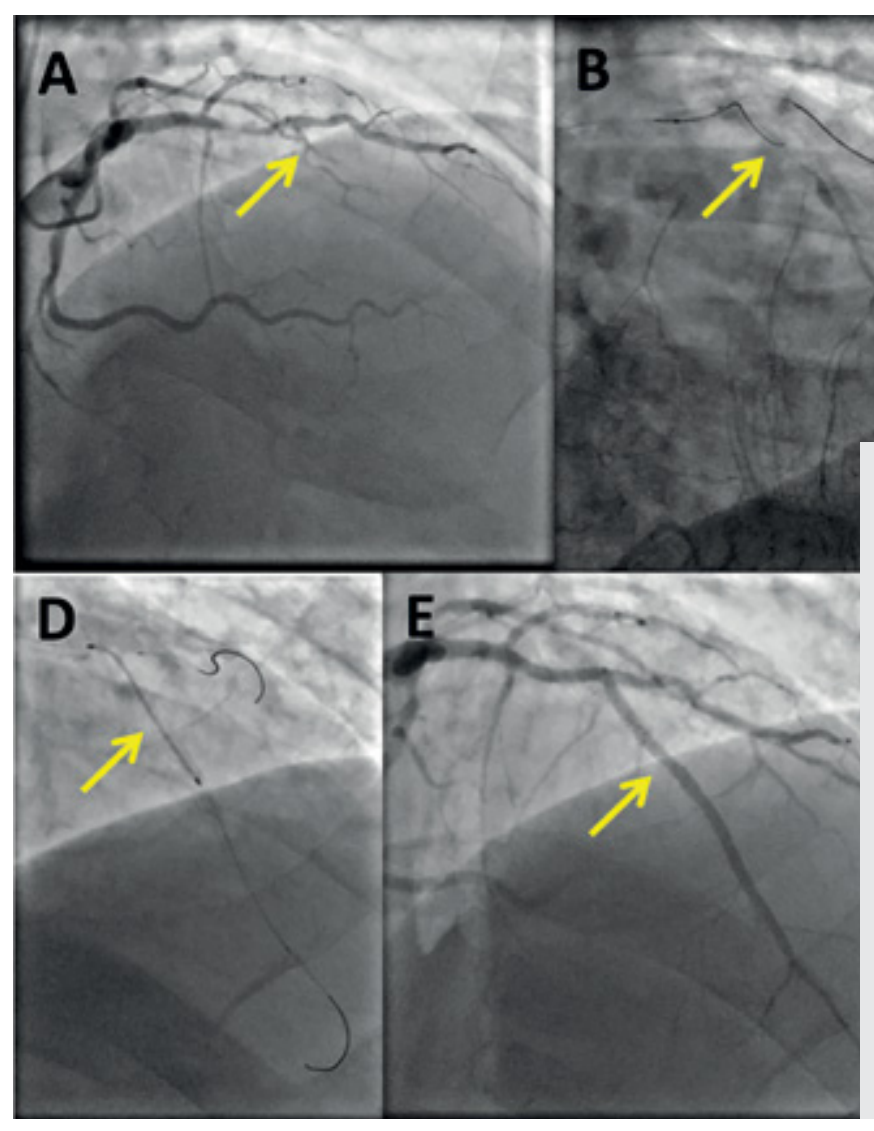

dissections from the rapidly exploding bubbles (13-15). In the ELLEMENT (Excimer Laser Lesion Modification to Expand Non-dilatable sTents) registry 28 undilatable stented coronary lesions were treated with laser using the following technique: if non-compliant balloon predilation was unsuccessful, ELCA was applied with gradual increase of the fluency and repetition rates. If optimal stent expansion could not be achieved, laser was performed with contrast injection at the highest fluency and repetition rates $\left(80 \mathrm{~mJ} / \mathrm{mm}^{2}\right.$ and $80 \mathrm{~Hz}$ using the 0.9 $\mathrm{mm}$ catheter). Laser-assisted stent dilatation was successfully achieved in $96.4 \%$, periprocedural myocardial infarction occurred in $7.1 \%$, transient slow-flow in $3.6 \%$ and ST-segment elevation in $3.6 \%$ (16).

Balloon uncrossable lesions can be challenging to treat and are defined as lesions that cannot be crossed with a balloon after successful guidewire crossing (Figure 2). These lesions are relatively common: they represented $6.4 \%, 24$ of 373 consecutive CTO lesions in a single center study (in this series ELCA was used in $8.7 \%$ of the cases) (17) and 9\%, 63 of 718 lesions in a multicenter CTO registry (ELCA was used in $18 \%$ of the lesions) (18). In the previously mentioned study by Fernandez et al, ELCA was used in 36 patients with balloon uncrossable lesions. Among these patients, 16 were CTOs $(44 \%)$ and procedural success was achieved in $13(81 \%)$, with one patient developing transient no reflow. The other 20 lesions were in non-occlusive lesions and ELCA use was associated with procedural success in $17(85 \%)$ of them. Ten lesions were only

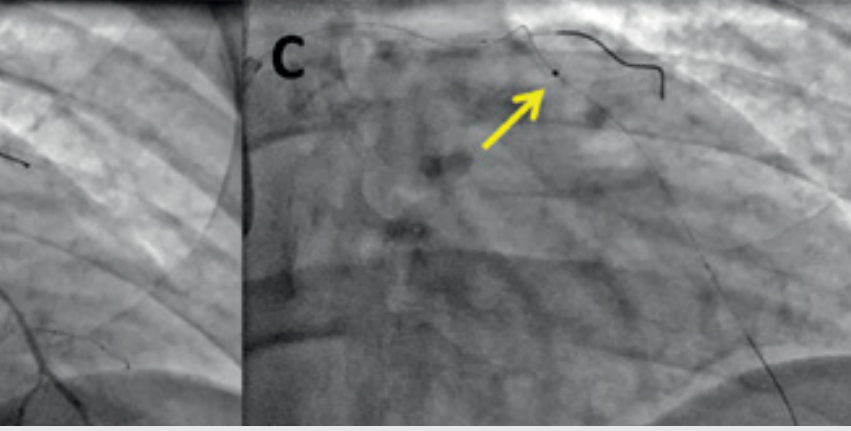

FIGURE 2. Use of ELCA in a balloon uncrossable chronic total occlusion. A 65-year-old man with history of diabetes and hypertension was referred for treatment of a left anterior descending artery (LAD) chronic total occlusion (CTO) (arrow, PANEL A). The left main was engaged with an 8 French $(\mathrm{Fr}) \mathrm{XB} 3.5$ guide catheter and the right coronary artery was engaged with a $6 \mathrm{Fr}$ diagnostic catheter. Antegrade crossing was attempted using a Fielder XT (Asahi Intecc) and Cross-lt (Abbott Vascular) guidewires without success (arrow, PANEL B). A Pilot 200 guidewire (Abbott Vascular) with the support of an OTW balloon crossed the lesion; however, no other balloon nor the CrossBoss catheter (Boston Scientific) could cross the lesion. ELCA was used (arrow, PANEL C), successfully crossing the mid-LAD CTO. After balloon predilation, four drug-eluting stents were deployed (arrow, PANEL D) with an excellent final result (PANEL E) and no complications. Figure reproduced from "Textbook of Atherectomy" with the permission of Dr. Nicolas Shammas.

treated with ELCA, whereas both ELCA and rotational atherectomy were used in the remaining 7 lesions (10). In the Laser Veterans Affair (LAVA) multicenter registry enrolled 130 target lesions in 121 consecutive PCls, the most common indication for ELCA was balloon uncrossable lesions (43.8\%) with technical success of $87.8 \%$ and procedural success of $83.7 \%$. (13) Laser can be combined in balloon uncrossable lesions with rotational atherectomy ("RASER" technique): ELCA is first used to cross the lesion and facilitates the passing of a rotational atherectomy wire followed by rotablation (19). In addition to the previous applications, ELCA can be a valuable tool in management of intracoronary thrombus (Figure 3). Laser can induce shock waves that can separate thrombi from the vessel wall, so it can facilitate adjunctive thrombectomy (20). Furthermore ELCA also inhibits aggregation of platelets ("stunned platelet phenomenon") (21) and it can create photoacoustic dissolution of fibrin clots (22). The Cohort of Acute Revascularization in Myocardial Infarction with Excimer Laser (CARMEL) multicenter registry included $151 \mathrm{AMI}$ patients ( $54 \%$ Q wave and $46 \%$ non- $Q$ wave), several of whom had high-risk characteristics, such as cardiogenic shock (13\%) and saphenous vein graft as the target lesion (21\%). Laser use was successful in $95 \%$ of the cases with $91 \%$ overall procedural success; the largest effect on luminal enlargement was among cases with large thrombus burden. Dissection occurred in $5 \%$, perforation in $0.6 \%$, distal vessel occlusion in $0.6 \%$, and distal embolization in $2 \%(23)$. 


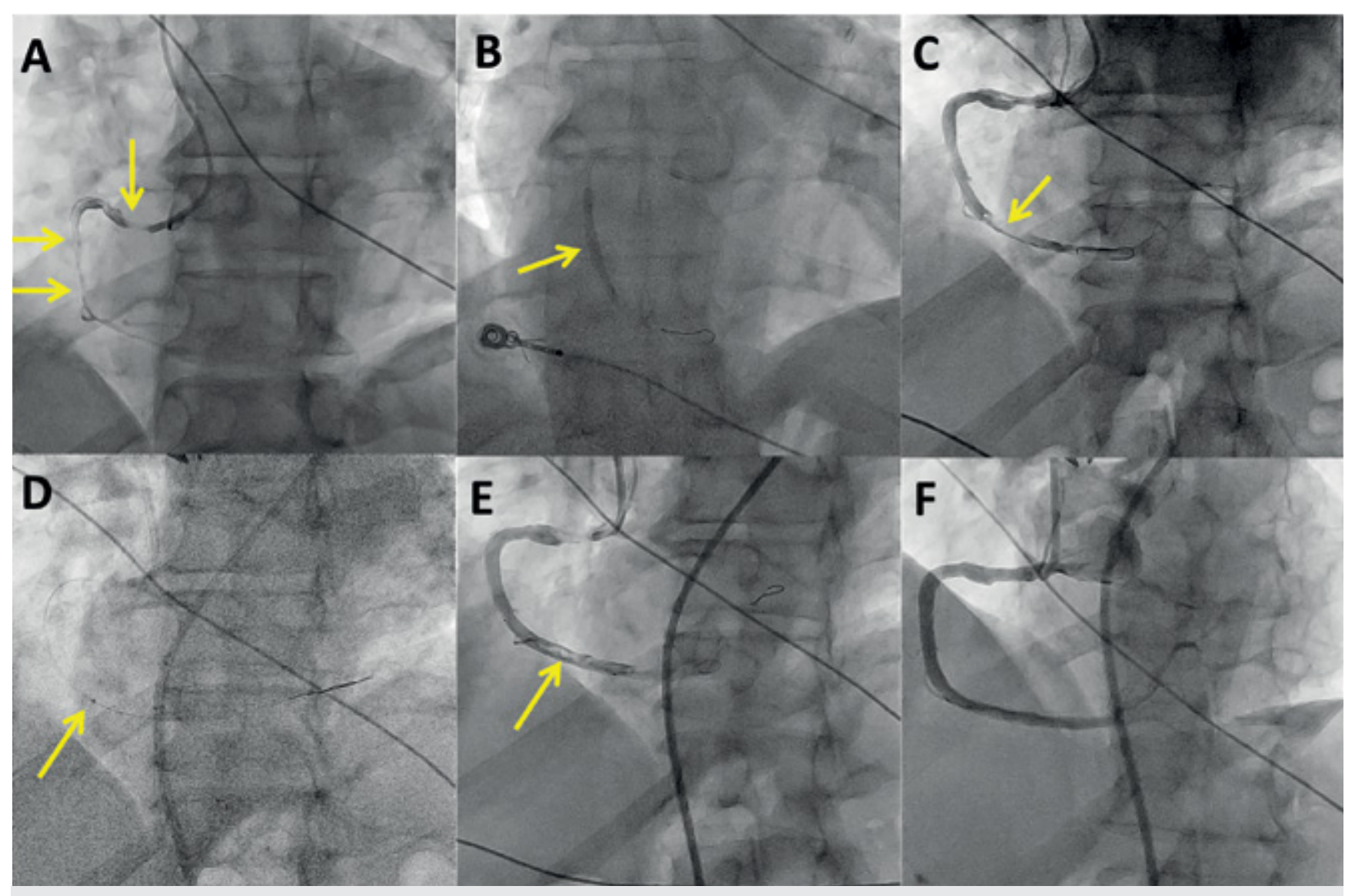

FIGURE 3. Use of ELCA to treat intracoronary thrombus. A 67-year-old man with a history of hypertension, peripheral arterial disease, and smoking presented with inferior ST-segment elevation acute myocardial infarction. After aspirin and clopidogrel preloading, coronary angiography revealed moderate stenosis of the left anterior descending artery (LAD) and the circumflex artery (Cx) and thrombotic occlusion of right coronary artery (RCA). The RCA was engaged with a 6 French JR 4 guide and the distal RCA was wired successfully with a 0.014-inch guidewire. In spite of several rounds of aspiration thrombectomy and predilation with a $2.0 \times 30 \mathrm{~mm}$ balloon (arrow, PANEL B), significant thrombus burden remained (arrow, PANEL C). Thrombectomy was repeated through a 6 French guide catheter extension without success. Intravascular ultrasound confirmed intraluminal wire position and large thrombus burden. ELCA using a 0.9-mm Turbo-Elite catheter (arrow, PANEL D) was performed (fluency $80 \mathrm{~mJ} / \mathrm{mm}^{2}$ and frequency $80 \mathrm{~Hz}$ ) with some improvement (arrow, PANEL E). The 6 Fr right radial access was converted to 8 Fr left femoral followed by repeat aspiration through an $8 \mathrm{Fr}$ guide catheter extension and lasing with significant flow improvement and resolution of intracoronary thrombus. After implantation of 3 overlapping drug-eluting stents, TIMI 3 flow was restored with $0 \%$ residual stenosis (PANEL F). The patient had an uneventful recovery. Figure reproduced from "Textbook of Atherectomy" with the permission of Dr. Nicolas Shammas

ELCA can also be used in saphenous vein graft (SVG) lesions that often have large thrombus burden with high risk of distal embolization and in-stent restenosis. Ebersole et al enrolled 31 patients for laser angioplasty whose infarct related vessel was a SVG. Device success rate was $87 \%$, angiographic success rate was $97 \%$, and the overall procedural success rate was $84 \%$. There were 3 cases of dissection (10\%), one caused by the guidewire and 2 by the laser, and 3 cases of no reflow (one laser induced, one due to stent, and one due to use of a transluminal extraction catheter). There were no acute closures, distal embolization of perforations (24). In the "Coronary graft Results following Atherectomy with Laser" (CORAL) multicenter registry 98 patients with $>50 \%$ SVG stenosis were treated with ELCA. Inclusion and exclusion criteria in this study were aligned to those in the saphenous vein graft Angioplasty Free of Emboli Randomized (SAFER) trial. The CORAL trial found that patients treated with laser had similar rates of no reflow $(5.1 \%$ vs. $3 \%, p=0.37)$ and $a b-$ rupt closure $(3.0 \%$ vs. $1.7 \%, p=0.40)$, but higher 30 -day incidence of major adverse cardiac events $(18.4 \%$ vs. $9.6 \%, p=0.02$ ) as compared with patients who received an embolic protection device in the SAFER trial $(8,25)$. ELCA may, therefore, be useful in SVG lesions especially when embolic protection device use is not feasible. In highly complex lesions, such as CTOs ELCA could facilitate crossing of an "impenetrable proximal cap" after withdrawing the guidewire (26). This technique should be applied only by experienced operators, as 
it carries risk of perforation. The laser should only be advanced for a very short distance $(0.5 \mathrm{~mm}$ or less) to modify the proximal cap enough to allow subsequent guidewire penetration $(8,9)$.

\section{Conclusions}

ELCA can facilitate treatment of complex coronary lesions, such as balloon uncrossable and undilatable lesions, highly thrombotic and SVG lesions. Meticulous attention to optimal technique is necessary to achieve the best possible clinical outcomes.

\section{Declaration of interest}

Dr. Brilakis: consulting/speaker honoraria from Abbott Vascular, American Heart Association (associate editor Circulation), Amgen, Biotronik, Boston Scientific, Cardiovascular Innovations Foundation (Board of Directors), ControlRad, CSI, Ebix, Elsevier, GE Healthcare, InfraRedx, Medtronic, Siemens, and Teleflex; research support from Regeneron and Siemens. Shareholder: MHI Ventures.

The remaining authors have nothing to disclose.

\section{References}

1. Badr S, Ben-Dor I, Dvir D, et al. The state of the excimer laser for coronary intervention in the drug-eluting stent era. Cardiovasc Revasc Med 2013; 14(2): 93-8.

https://doi.org/10.1016/j.carrev.2012.12.008

2. Egred M, Brilakis ES. Excimer Laser Coronary Angioplasty (ELCA): Fundamentals, Mechanism of Action, and Clinical Applications. J Invasive Cardiol 2020; 32(2): E27-E35.

3. Topaz O. Lasers in Cardiovascular Interventions. 1 ed: SpringerVerlag London; 2015.

4. Klein LW, Litvack F, Holmes D, et al. Six month outcome and determinants of adverse clinical events after successful excimer laser coronary angioplasty. ELCA A.I.S. Multicenter Registry. J Invasive Cardiol 1995; 7(7): 191-9.

https://doi.org/10.15420/icr.2016:2:2

5. Reifart N, Vandormael M, Krajcar M, et al. Randomized comparison of angioplasty of complex coronary lesions at a single center. Excimer Laser, Rotational Atherectomy, and Balloon Angioplasty Comparison (ERBAC) Study. Circulation 1997; 96(1): 91-8.

https://doi.org/10.1161/01.cir.96.1.91

6. Cook SL, Eigler NL, Shefer A, et al. Percutaneous excimer laser coronary angioplasty of lesions not ideal for balloon angioplasty. Circulation 1991; 84(2): 632-43.

https://doi.org/10.1161/01.cir.84.2.632

7. Appelman YE, Koolen JJ, Piek JJ, et al. Excimer laser angioplasty versus balloon angioplasty in functional and total coronary occlusions. Am J Cardiol 1996; 78(7): 757-62.

https://doi.org/10.1016/s0002-9149(96)00416-x

8. Shammas N. Textbook of Atherectomy: HMP Communications; 2016.

9. Brilakis ES. Manual of Chronic Total Occlusion Interventions, A Step-by-Step Approach. $2^{\text {nd }}$ Edition ed: Elsevier; 2018.

10. Fernandez JP, Hobson AR, McKenzie D, et al. Beyond the balloon: excimer coronary laser atherectomy used alone or in combination with rotational atherectomy in the treatment of chronic total occlusions, non-crossable and non-expansible coronary lesions. Eurolntervention 2013; 9(2): 243-50.
https://doi.org/10.4244/EIJV9I2A40

11. Ambrosini V, Sorropago G, Laurenzano E, et al. Early outcome of high energy Laser (Excimer) facilitated coronary angioplasty $\mathrm{ON}$ hARD and complex calcified and balloon-resistant coronary lesions: LEONARDO Study. Cardiovasc Revasc Med. 2015; 16(3): 141-6.

12. Karacsonyi J, Armstrong EJ, Truong HTD, et al. Contemporary Use of Laser During Percutaneous Coronary Interventions: Insights from the Laser Veterans Affairs (LAVA) Multicenter Registry. J Invasive Cardiol 2018; 30(6): 195-201.

13. Karacsonyi J, Danek BA, Karatasakis A, et al. Laser Coronary Atherectomy During Contrast Injection for Treating an Underexpanded Stent. JACC Cardiovasc Interv 2016; 9(15): e147-8.

https://doi.org/10.1016/j.jcin.2016.04.040

14. Egred M. A novel approach for under-expanded stent: excimer laser in contrast medium. J Invasive Cardiol 2012; 24(8): E161-3.

15. Ashikaga T, Yoshikawa S, Isobe M. The effectiveness of excimer laser coronary atherectomy with contrast medium for underexpanded stent: The findings of optical frequency domain imaging. Catheter Cardiovasc Interv 2015; 86(5): 946-9.

https://doi.org/10.1002/ccd.25915

16. Latib A, Takagi K, Chizzola G, et al. Excimer Laser LEsion modification to expand non-dilatable stents: the ELLEMENT registry. Cardiovasc Revasc Med 2014; 15(1): 8-12.

https://doi.org/10.1016/j.carrev.2013.10.005

17. Patel SM, Pokala NR, Menon RV, et al. Prevalence and treatment of "balloon-uncrossable" coronary chronic total occlusions. J Invasive Cardiol 2015; 27(2): 78-84.

18. Karacsonyi J, Karmpaliotis D, Alaswad K, et al. Prevalence, indications and management of balloon uncrossable chronic total occlusions: Insights from a contemporary multicenter US registry. Catheter Cardiovasc Interv. 2017; 90(1): 12-20.

https://doi.org/10.1002/ccd.26780

19. McKenzie DB, Talwar S, Jokhi PP, et al. How should I treat severe coronary artery calcification when it is not possible to dilate a balloon or deliver a RotaWire? Eurolntervention 2011; 6(6): 779-83. https://doi.org/10.4244/EIJV6I6A132

20. Ben-Dor I, Maluenda G, Pichard AD, et al. The use of excimer laser for complex coronary artery lesions. Cardiovasc Revasc Med 2011; $12(1)$ : 69 e1-8.

https://doi.org/10.1016/j.carrev.2010.06.008

21. Topaz O, Minisi AJ, Bernardo NL, et al. Alterations of platelet aggregation kinetics with ultraviolet laser emission: the "stunned platelet" phenomenon. Thromb Haemost 2001; 86(4): 1087-93.

22. Topaz O, Minisi AJ, Morris C, et al. Photoacoustic Fibrinolysis: Pulsed-Wave, Mid-Infrared Laser-Clot Interaction. J Thromb Thrombolysis 1996; 3(3): 209-14.

https://doi.org/10.1007/BF00181663

23. Topaz O, Ebersole D, Das T, et al. Excimer laser angioplasty in acute myocardial infarction (the CARMEL multicenter trial). Am J Cardiol 2004; 93(6): 694-701.

https://doi.org/10.1016/j.amjcard.2003.11.050

24. Ebersole D, Dahm JB, Das T, et al. Excimer laser revascularization of saphenous vein grafts in acute myocardial infarction. J Invasive Cardiol 2004; 16(4): 177-80.

25. Giugliano GR, Falcone MW, Mego D, et al. A prospective multicenter registry of laser therapy for degenerated saphenous vein graft stenosis: the COronary graft Results following Atherectomy with Laser (CORAL) trial. Cardiovasc Revasc Med 2012; 13(2): 84-9. https://doi.org/10.1016/j.carrev.2012.01.004

26. Sapontis J, Grantham JA, Marso SP. Excimer laser atherectomy to overcome intraprocedural obstacles in chronic total occlusion percutaneous intervention: Case examples. Catheter Cardiovasc Interv 2015; 85(3): E83-9. https://doi.org/10.1002/ccd.25680 